\title{
Response of suspended sediment concentration to tidal dynamics at a site inside the mouth of an inlet: Jiaozhou Bay (China)
}

\author{
S.L. Yang, J. Zhang and J. Zhu \\ State Key Lab of Estuarine and Coastal Research, East China Normal University, Shanghai 200062, China \\ E-mail for corresponding author: slyang@sklec.ecnu.edu.cn
}

\begin{abstract}
Observations of fair weather currents and suspended sediment concentrations (SSC) were made using an acoustic Doppler current profiler and two YSI turbidity sensors over a neap to spring time cycle at a site near the inner mouth of a semi-enclosed mesotidal-macrotidal embayment (Jiaozhou Bay) to examine the influence of tidal dynamics on concentration and transport of suspended sediment. During the investigation, SSC varied from about 3 to $16 \mathrm{mg} \mathrm{L}^{-1}$ at the surface and about 6 to $40 \mathrm{mg} \mathrm{L}^{-1}$ close to the bed, while the current velocity reached $79 \mathrm{~cm} \mathrm{~s}^{-1}$ at the surface and $61 \mathrm{~cm} \mathrm{~s}^{-1}$ near the bed. SSC was tidally cyclic. The near-bed instantaneous SSC was closely related to current velocity with almost no time lag, indicating that the variability of SSC was governed by current-induced settling/resuspension. At the surface, however, instantaneous SSC was poorly related to instantaneous current velocity because the peak SSC tended to occur around ebb slack water. This suggests that the surface SSC was controlled by horizontal advection from landward higher concentration areas. Both at the surface and near the bed, on the other hand, tidally-averaged SSC was well correlated to tidal range and current speed. Current velocity and SSC were flood-dominated for all the tides investigated, which resulted in significant landward residual suspended sediment transport at the study site. The observed flood dominance was mainly attributed to the location of the study site on the landward side of the bay's inlet where flow separation is favoured during flood tide. It was concluded that tides are the dominant hydrodynamic component controlling the variability of SSC during fair weather at the study area.
\end{abstract}

Keywords: sediment, concentration, suspension, advection, currents, shoaling effect, Jiaozhou Bay, China

\section{Introduction}

Knowledge of dynamics of suspended sediments in estuarine and coastal areas is of great importance in determining the fate and transport of suspended sediment and sediment adherent contaminants. The variability of suspended sediment concentration (SSC) and the causes for it are meaningful not only in sedimentology, geomorphology and engineering but also in biology, ecology and biogeochemistry (Lindsay et al., 1996). SSC in coastal waters is influenced by tidal dynamics and, consequently, may vary on semidiurnal, fortnightly and seasonal time scales. Tidal dynamics is one of the key factors governing the variability of SSC, especially in muddy mesotidal and macrotidal environments (including estuaries, gulfs, bays, tidal channels and intertidal zones) (Alvarez and Jones, 2002; Uncles et al., 2002). Tidal (semidiurnal or diurnal) and neap-spring cyclic variations are dominant scales of temporal variations in suspended sediment dynamics and have received significant attention (Gelfenbaum, 1983; Ridderinkhof et al., 2000; Schoellhamer, 2002). The flood or ebb dominance of current and SSC has been a particular focus, given its significance in determining the direction and extent of net sediment fluxes (Dyer et al., 2000).

Although numerous studies have been made on suspended sediment dynamics, further work is needed to understand the exact relation of sediment transport to hydrodynamics because of the uncertainties concerning the specific characteristics of sediment and hydrodynamic forcing (Hill et al., 2003). The purpose of this study was to examine the influence of tidal and neap-spring conditions on suspended sediment dynamics in a semi-closed mesotidal-macrotidal bay. Four objectives were identified: (1) to measure the temporal and vertical changes in currents and SSC at high resolution using advanced monitoring instruments; (2) to quantify the flood, ebb and residual suspended sediment flux; (3) to examine statistical relationships among tidal 
dynamics, SSC, and hysteresis in SSC; and (4) to determine the relative importance of settling/resuspension versus horizontal advection in tidally cyclic variation in SSC.

\section{Study area}

Jiaozhou Bay is a semi-enclosed water body situated in the western Yellow Sea. The bay consists of a broad main portion of about $30 \mathrm{~km}$ in diameter and a mouth $3 \mathrm{~km}$ wide (Fig. 1). The bay is about $390 \mathrm{~km}^{2}$ in area at high tide (Shen, 2001) and about $256 \mathrm{~km}^{2}$ at low tide (Gao and Wang, 2002). The bay is surrounded by hills $50 \mathrm{~m}$ to $400 \mathrm{~m}$ high, except for small alluvial plains near the bay head. The mean and maximum wave heights are less than $0.4 \mathrm{~m}$ and 1.5 to $1.9 \mathrm{~m}$ at three wave stations located within the bay. Outside the bay, however, waves are typically greater; the maximum wave height recorded was $3.1 \mathrm{~m}$ (FIO, 1984). Tides in the bay are semi-diurnal; with a mean and maximum tidal range of $2.80 \mathrm{~m}$ and $4.75 \mathrm{~m}$, respectively (Gao and Wang, 2002). The spring tidal range is about 2.2 times higher than the neap tidal range. According to the classification of Davies (1964), the bay is transitional between mesotidal and macrotidal. Tides in the bay are similar to those outside the bay (FIO, 1984). The water depth, which is about $7 \mathrm{~m}$ on average, increases towards the mouth of the bay where it reaches a maximum of $64 \mathrm{~m}$ (Fig. 1 and Gao and Wang, 2002). Although more than 10 small rivers enter the bay, their total runoff is less than $5 \%$ of the mean tidal water discharge, even in a wet summer. During neap and spring tides, the tidal prism is about $1 / 5$ and $2 / 5$ of the bay volume, respectively (unpublished data of the co-authors), indicating the bay water is frequently refreshed by the water of the Yellow Sea. Between the 1950s and 1970s, about $1.6 \times 10^{6}$ to $2.0 \times 10^{6} \mathrm{t} \mathrm{y}^{-1}$ suspended sediment was transported into the bay by the rivers (Li, 1983; Li et al., 1992; Qiao et al., 1994). Since then, less than $0.05 \times 10^{6} \mathrm{t}^{-1}$ sediment has been derived from the rivers due to human activities in the drainage basins, including dam construction and water withdrawal (unpublished data of the co-authors). Before the 1980 s, accretion at a rate of a few $\mathrm{mm} \mathrm{y}^{-1}$ occurred in the Bay. Since then, however, accretion has stopped due to the reduction in the supply of riverine sediment (Hu et al., 2000). Deposits in the bay are dominated by mud (silt and clay). According to a grain size dataset of 53 bed sediment samples provided by Wang (2000), $\mathrm{D}_{50}$ is $0.019 \mathrm{~mm}(5.71 \Phi)$, and the percentages of clay $(<0.004 \mathrm{~mm})$ and silt $(0.004 \sim 0.063$

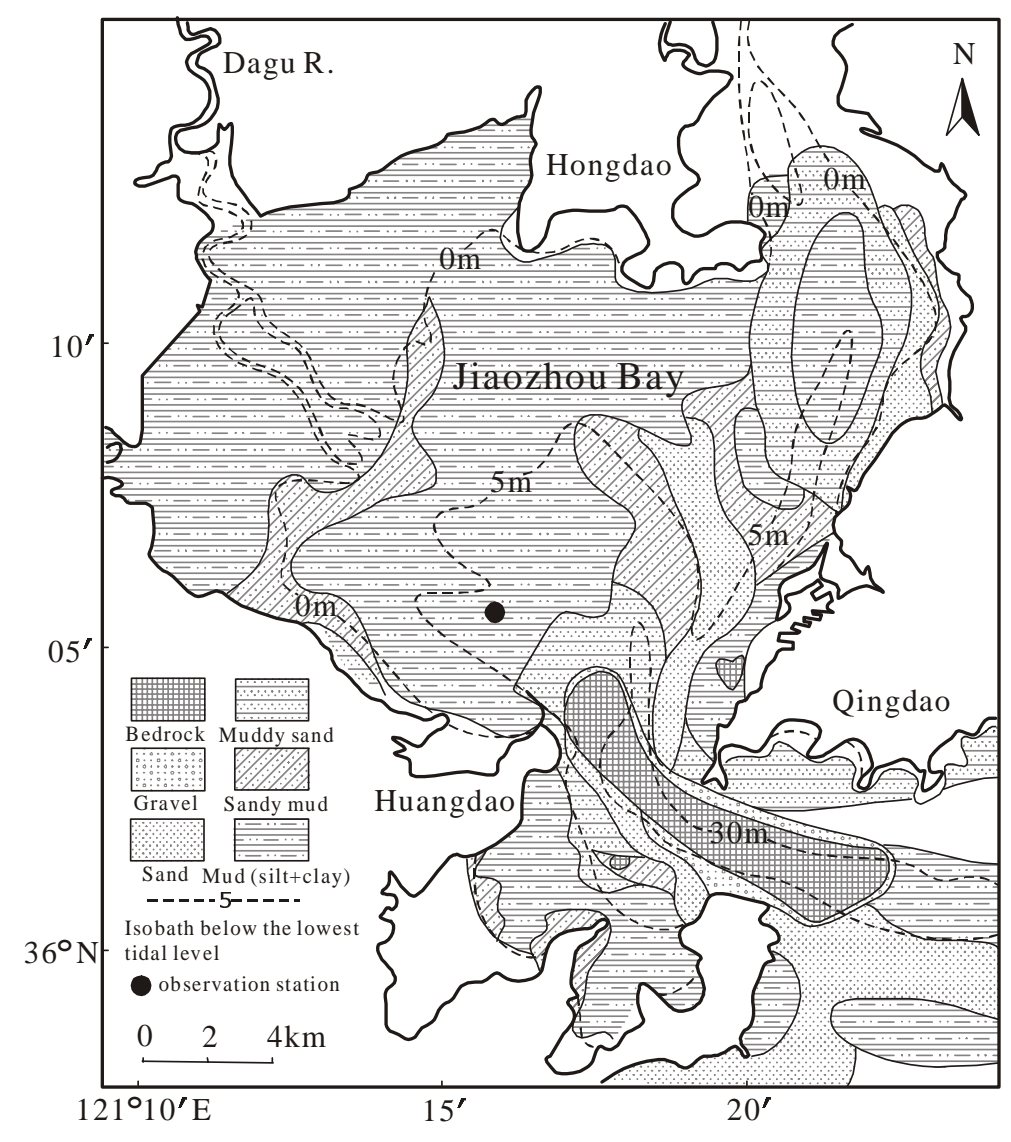

Fig. 1. Sketch map of Jiaozhou Bay showing depth, bed sediments and study site 
$\mathrm{mm}$ ) average $56.3 \%$ and $23.1 \%$, respectively. The bed of the gorge connecting the bay and the open sea is typically bedrock and mixture of sand and gravel (Fig.1).

\section{Materials and methods}

\section{FIELD OBSERVATIONS}

A field investigation base from an anchored vessel was carried out between August 13 and August 20, 2001, from neap to spring tides, in the vicinity of the bay mouth $\left(36^{\circ} 05.072^{\prime} \mathrm{N} ; 120^{\circ} 13.113^{\prime} \mathrm{E}\right)$ (Fig. 1). Two environmental monitoring systems made by YSI Company in USA, each incorporating a turbidity sensor, were employed for surface and near-bed measurement of turbidity, salinity and temperature. The surface system was set $0.5 \mathrm{~m}$ beneath the water surface and the near-bed system was maintained 16 $\mathrm{m}$ beneath the water surface (the mean depth was $19 \mathrm{~m}$ ). An Optical Backscatter Sensor (OBS) was used to measure vertical profiles of turbidity at slack waters and peak currents. Each vertical profile measurement was finished within $1 \mathrm{~min}$. Thus, turbidities at different levels were almost synchronous. An acoustic Doppler current profiler (ADCP) was vessel-mounted $0.5 \mathrm{~m}$ beneath the water surface for measurement of current velocity and direction at different levels. The time interval for data collection was $10 \mathrm{~min}$ for all the three instruments. Periodically, the instruments were pulled out of the water to confirm that they were working well. The exact time of these interruptions was recorded to facilitate elimination of invalid data. Water samples for SSC and salinity were collected from the levels of the two fixed turbidity sensors at different current velocities and tidal ranges using $2.5 \mathrm{~L}$ bottles. Sediment from the uppermost 5 $\mathrm{cm}$ of the seabed was sampled for grain size. During the investigation, the weather was calm and wave height was less then $0.3 \mathrm{~m}$ at the measurement station.

\section{ANALYSIS OF SAMPLES AND DATA PROCESSING}

Water samples were filtered through pre-weighed $0.45 \mu \mathrm{m}$ filters, which were dried at $60^{\circ} \mathrm{C}$. Grain size was measured using a Coulter LS 100Q that is suitable for grains from 0.25 to $1000 \mu \mathrm{m}$. To quantify the variations in SSC over varying time-scales, the data were classified. Each tide was divided into flood and ebb by dividing the time-series at each slack water. The tides were divided into neap tide, mean tide and spring tide according to their ranges. A regressive relationship between SSC and turbidity was established using the 61 water samples collected for calibration (Fig. 2 ). Based on this relationship, nearly 2000 turbidity measurements were converted into SSC values. The time lag of SSC relative to current velocity was examined

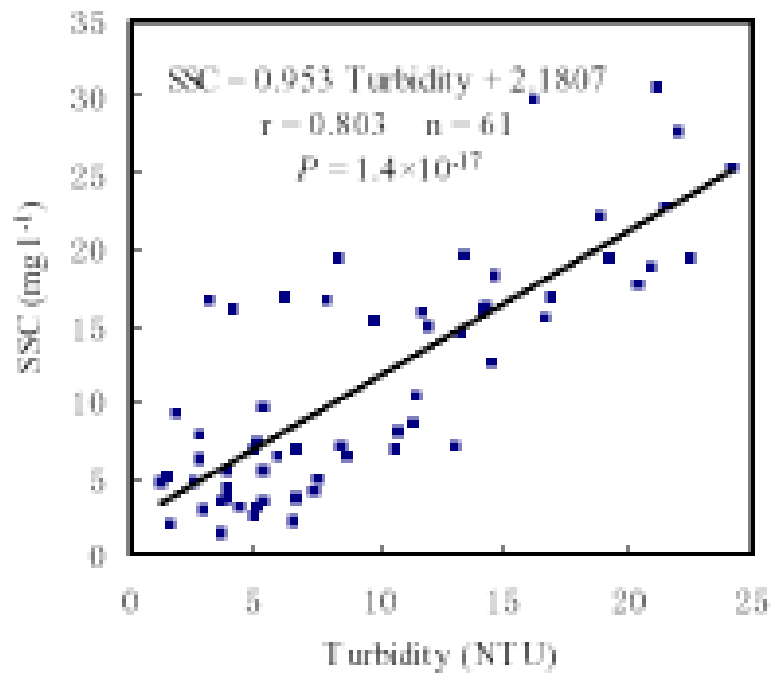

Fig.2. Correlation between turbidity and water sample SSC ( $r, n$ and $\mathrm{P}$ means correlation coefficient, number of samples and significance level, respectively)

statistically using the $10 \mathrm{~min}$ interval SSC and velocity data set and also by using tidally-averaged SSC and velocity values. The product of $10 \mathrm{~min}$ interval SSC and current velocity gives the 'instantaneous' suspended sediment fluxes through a cross section of unit area (Alvarez and Jones, 2002). The flood (or ebb) flux is then calculated as the integration of the instantaneous flux over the flood (or ebb) period. The residual suspended sediment flux for a single tide is the difference between flood and ebb fluxes.

\section{Results}

\section{TIDES AND CURRENTS}

The tidal range during the investigation increased from a neap minimum of $1.45 \mathrm{~m}$ on August 13 to a spring maximum of $4.34 \mathrm{~m}$ on August 20 (Fig. 3). At the surface, ADCP velocity ranged up to $49 \mathrm{~cm} \mathrm{~s}^{-1}$ during neap tides and $79 \mathrm{~cm}$ $\mathrm{s}^{-1}$ during spring tides and, near the bed, up to $30 \mathrm{~cm} \mathrm{~s}^{-1}$ during neap tides and $61 \mathrm{~cm} \mathrm{~s}^{-1}$ during spring tides. The dominant flood direction was around $330^{\circ}$, and the dominant ebb direction was about $150^{\circ}$. Generally, flood and ebb slack water occurred at high and low tide, respectively. The peak flood and ebb velocities occurred near the middle of the rising and falling tides, respectively (Fig. 3). Thus, the tide in this area is well represented by a standing wave. There was some fine scale variability in current velocity at shorter, intra-tidal time-scales. The important longer time scale was fortnightly, with spring velocity 1.7 to 2.3 times greater than neap velocity (Table 1). In addition, the current at the study site was consistently flood-dominated. On average, the flood velocity was 1.1 to 1.6 times greater than the ebb velocity. 


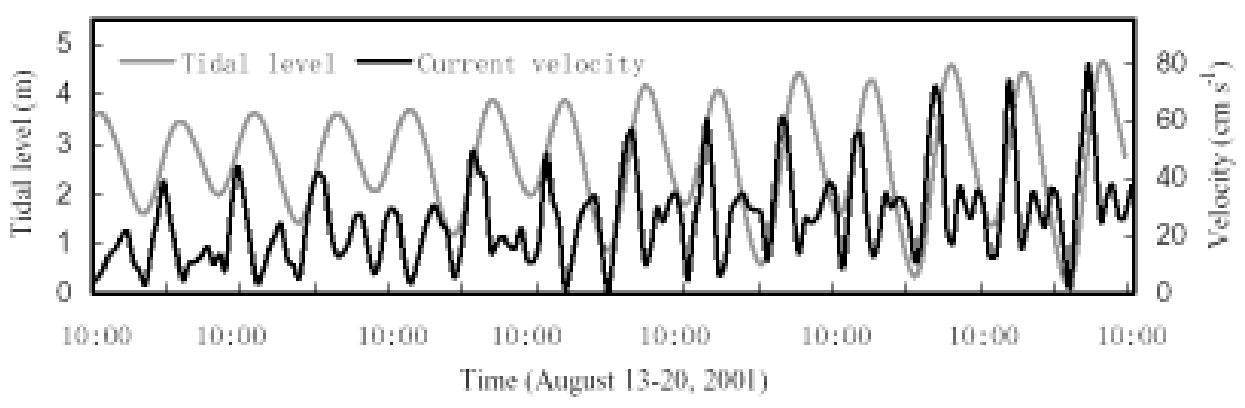

Fig.3. Time series of tidal level and current velocity

Table 1. Mean current velocity and SSC in different tidal conditions

\begin{tabular}{|c|c|c|c|c|c|c|c|c|c|c|c|c|}
\hline & \multicolumn{6}{|c|}{ Current velocity $\left(\mathrm{cm} \mathrm{s}^{-1}\right)$} & \multicolumn{6}{|c|}{$\mathrm{SSC}\left(\mathrm{mg} \mathrm{l}^{-1}\right)$} \\
\hline & \multirow{2}{*}{$\begin{array}{l}\text { Surface } \\
\text { Flood }\end{array}$} & \multirow{2}{*}{ Ebb } & \multirow[b]{2}{*}{$\begin{array}{l}\text { Flood } \\
\text { /Ebb }\end{array}$} & \multicolumn{3}{|c|}{ Near-bed $(0.85 \mathrm{H})$} & \multicolumn{2}{|l|}{ Surface } & \multirow[b]{2}{*}{$\begin{array}{l}\text { Flood } \\
\text { /Ebb }\end{array}$} & \multicolumn{3}{|c|}{ Near-bed $(0.85 \mathrm{H})$} \\
\hline & & & & Flood & Ebb & $\begin{array}{l}\text { Flood } \\
\text { /Ebb }\end{array}$ & Flood & Ebb & & Flood & $\mathrm{Ebb}$ & $\begin{array}{l}\text { Flood } \\
\text { /Ebb }\end{array}$ \\
\hline $\operatorname{Neap}(1.8$ m*) & $23 \pm 11$ & $14 \pm 5.1$ & 1.6 & $9.1 \pm 4.5$ & $8 . .5 \pm 4.4$ & 1.1 & $4.9 \pm 1.2$ & $4.3 \pm 1.1$ & 11.1 & $12 \pm 3.2$ & $11 \pm 3.0$ & 1.1 \\
\hline $\operatorname{Mean}\left(2.5 \mathrm{~m}^{*}\right)$ & $31 \pm 15$ & $21 \pm 6.7$ & 1.4 & $15+7.4$ & $13 \pm \overline{7} .8$ & 1.2 & $6.3 \pm 2.0$ & $5.5 \pm 1.6$ & 61.1 & $14 \pm 4.7$ & $12 \pm 3.2$ & 1.2 \\
\hline $\operatorname{Spring}\left(3.6 \mathrm{~m}^{*}\right)$ & $42 \pm 18$ & $26 \pm 7.2$ & 1.6 & $21 \pm 11$ & $17 \pm 9.6$ & 1.2 & $9.1 \pm 1.6$ & $8.0 \pm 2.1$ & 11.1 & $19 \pm 4.8$ & $16 \pm 4.1$ & 1.2 \\
\hline Spring/Neap & $1 . \overline{7}$ & $1.9^{-}$ & & $2.3^{-}$ & $2.0^{-}$ & & $1.9^{-}$ & $1.9^{-}$ & & $1 . \overline{6}$ & $1 . \overline{5}$ & \\
\hline
\end{tabular}

\section{VARIATIONS IN SSC}

SSC ranged from about 3 to $16 \mathrm{mg} \mathrm{L}^{-1}$ at the surface and from 6 to $40 \mathrm{mg} \mathrm{L}^{-1}$ near the bed (Figs. 4 and 5). During neap tides, the surface SSC was reduced to a 'background' (Schubel, 1968) concentration of about $3 \mathrm{mg} \mathrm{L}^{-1}$ which will be discussed in detail below. Nevertheless, SSC was tidally cyclic near the bed (Fig. 4) and at the surface during spring and mean tides (Fig. 5). Like velocity, SSC was also flood dominated. On average, the flood SSC was 1.13 times greater than the ebb SSC. At fortnightly time-scales, the spring SSC was 1.73 times higher than the neap SSC (Table 1). Superimposed upon the semi-diurnal cycle were higher-frequency fluctuations of SSC. These pulses are probably due to suspended sediment clouds (Green et al., 1995) that are related, in turn, to higher-frequency velocity pulses (Fig. 4).

SSC increased downwards. With its upper part convex and the lower part concave, the mean vertical profile of SSC was not rectilineal (Fig. 6). On average, SSC was about 2.7 times greater near the bed than at the surface. The difference between near-bed SSC and surface SSC was greater during peak currents than during slack waters, probably because sediments resuspended from the bed reached only to the lower water column even when velocities were high.

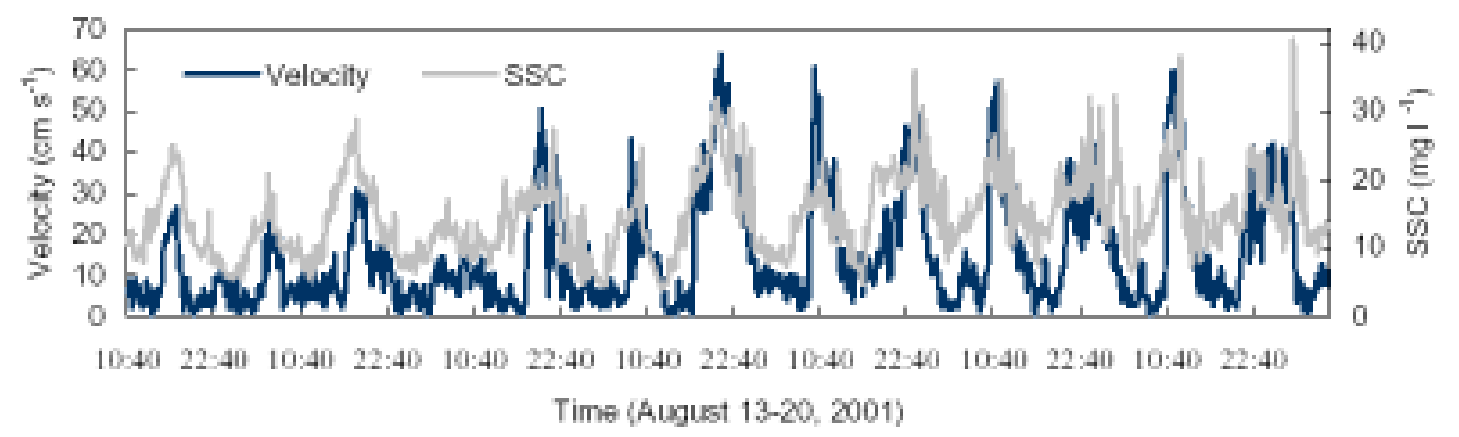

Fig.4. Time series of current velocity and SSC at the near-bed level 


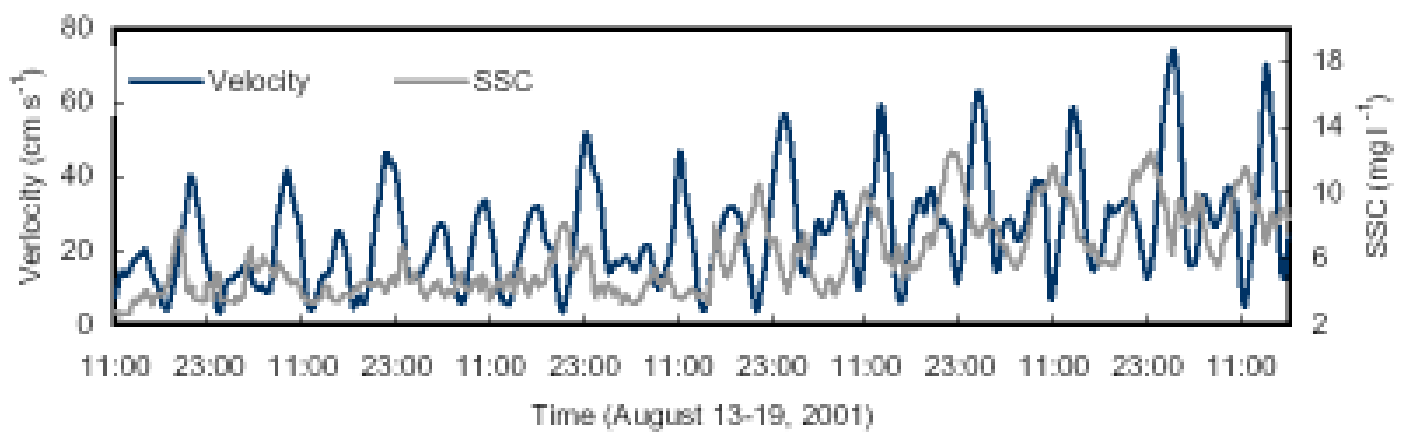

Fig. 5. Time series of current velocity and SSC at the near-surface level (50 min consecutive average; the higher and lower velocity pinnacles indicating flood and ebb, respectively)

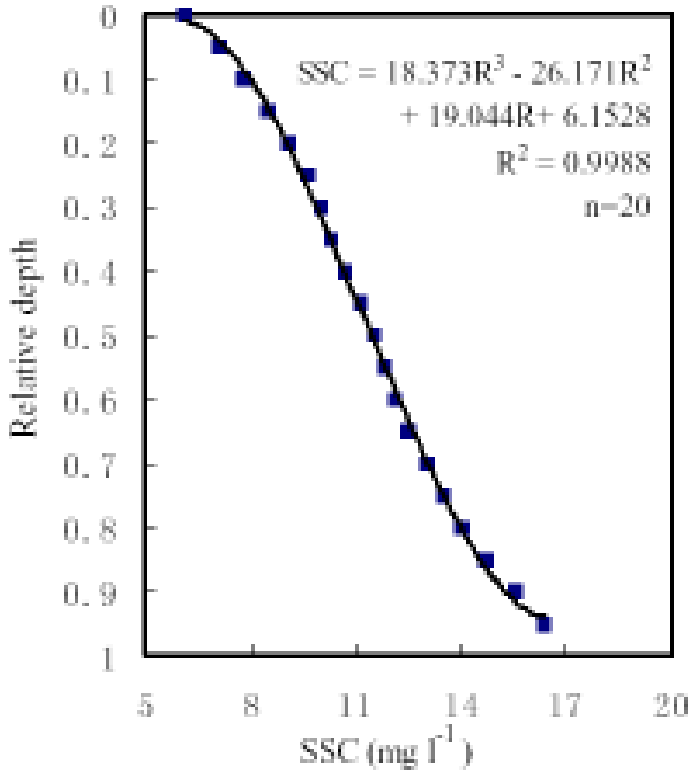

Fig.6. Mean vertical profile of SSC based on vertical profiles of turbidity at different tidal dynamics (Relative depth is the ratio of turbidity sensor level below surface to water depth)

RELATIONSHIP BETWEEN SSC AND TIDAL

\section{DYNAMICS}

\section{Near-bed level}

At the near-bed level, the semi-diurnal variation in SSC was generally in phase with the current velocity (Fig. 4). This suggests that the near-bed SSC responded directly to the change in velocity. It is reasonable that an increase in current velocity enhanced resuspension of bed sediments, while a decrease in current velocity resulted in settling of suspended sediments. Statistically, SSC is positively and significantly correlated with current velocity and tidal range. Figures 7 and 8 show the correlation between SSC and current velocity based on $10 \mathrm{~min}$ and tidally-averaged data, respectively. Despite the large amount of scatter, the large number of

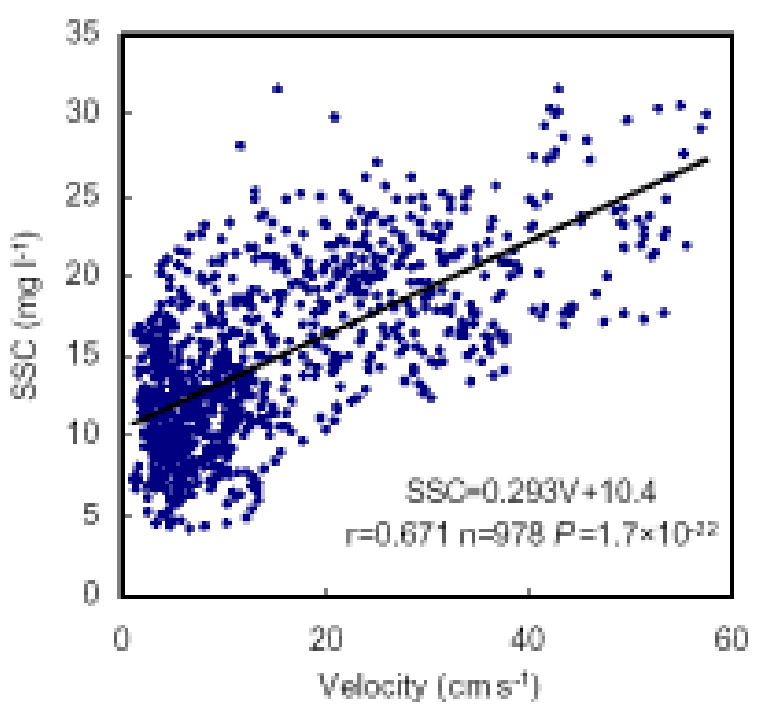

Fig.7. Correlation between current velocity and SSC at the near-bed level $(V, r, n$ and $\mathrm{P}$ means current velocity, correlation coefficient, number of samples and significance level, respectively)

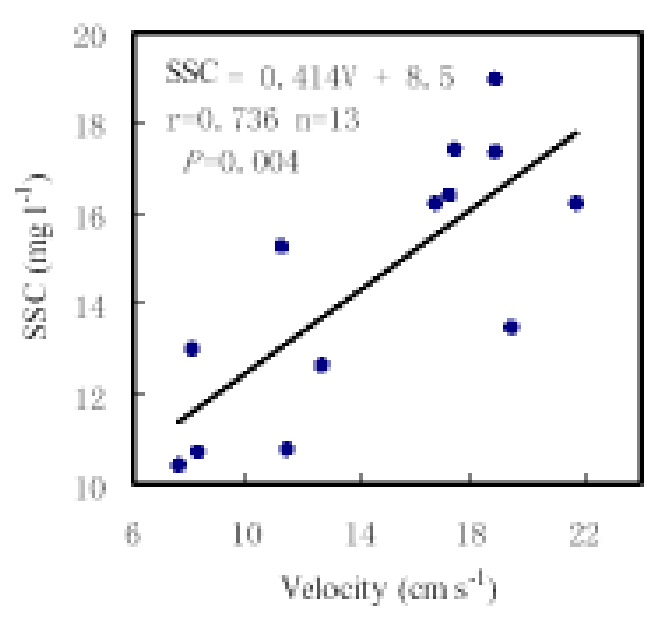

Fig. 8. Correlation between tidally-averaged current velocity and $S S C$ at the near-bed level $(V, r, n$ and $\mathrm{P}$ means current velocity, correlation coefficient, number of samples and significance level, respectively) 
Table 2. Correlative coefficient (r) and significant level $(P)$ of the linear regressive relationships between SSC and tidally-averaged velocity (V)/tidal range (R) at the near-bed level.

\begin{tabular}{|c|c|c|c|c|c|}
\hline & & \multicolumn{2}{|c|}{ Correlative coefficient (r) } & \multicolumn{2}{|c|}{ Significant level $(P)$} \\
\hline & & Velocity-SSC & Tidal range-SSC & Velocity-SSC & Tidal range-SSC \\
\hline \multirow[t]{2}{*}{ Near-bed $(0.85 \mathrm{H})^{*}$} & In-phase & 0.736 & 0.876 & $4.1 \times 10^{-3}$ & $8.7 \times 10^{-5}$ \\
\hline & 1 tide lag & 0.596 & 0.246 & 0.041 & 0.442 \\
\hline \multirow[t]{3}{*}{ Surface } & In-phase & 0.968 & 0.880 & $3.5 \times 10^{-6}$ & $9.0 \times 10^{-4}$ \\
\hline & 1 tide lag & 0.970 & 0.581 & $3.1 \times 10^{-6}$ & 0.074 \\
\hline & 2 tides lag & 0.964 & 0.849 & $6.9 \times 10^{-6}$ & $1.9 \times 10^{-3}$ \\
\hline
\end{tabular}

*Both the 2-tides-lag Velocity-SSC and the 2-tides-lag Tidal range-SSC correlations are not significant (Significant means $P<0.05$ ).

data points in Fig. 7 result in a relationship which is significant, statistically. The scattering of points may reflect the influence of several factors such as waves, horizontal advection, distance from the bottom, pulses of current velocity responsible for sediment clouds and biological action, etc. These influences may complicate the response of SSC to local current velocity. The correlation coefficients between SSC and velocity of the flood and ebb stages are equal, suggesting that the response of SSC to tidal currents was uniform during the two stages. In addition, SSC was significantly correlated with tidal range (Table 2).

\section{Surface level}

Near the surface, SSC was not in phase with current velocity for either $10 \mathrm{~min}$ interval data or $50 \mathrm{~min}$ consecutive average data. The highest SSC often occurred around the ebb slack water (Fig. 5), which is consistent with the observations of Dyer et al. (2000) in the Dollard Estuary. The correlation $(\mathrm{r}<0.2)$ between $10 \mathrm{~min}$ interval SSC and current velocity is much less significant than the corresponding near-bed correlation. However, the near-surface tidally-averaged SSC is correlated significantly with tidally-averaged current speed and tidal range (Fig. 9 and Table 2). Figure 9 shows that SSC is positively correlated with the square of velocity.

\section{TIME LAG OF SSC}

Statistically, the time lag of SSC is complicated. At the surface, the In-phase, 1-tide-lag and 2-tide-lag SSC-Velocity correlations have similar high $\mathrm{r}$ and low $P$ values, but the 1 tide-lag SSC-Tidal range correlation is much less significant than the In-phase and 2-tide-lag correlations (Table 2). Near the bed, the 1-tide-lag SSC-Velocity correlation has much lower $r$ and higher $P$ than the In-phase correlation, although the former is almost significant $(P<0.05)$. The 1-tide-lag Tidal range-SSC correlation is far below the significance level (Table 2). Neither the 2-tide-lag Velocity-SSC nor the

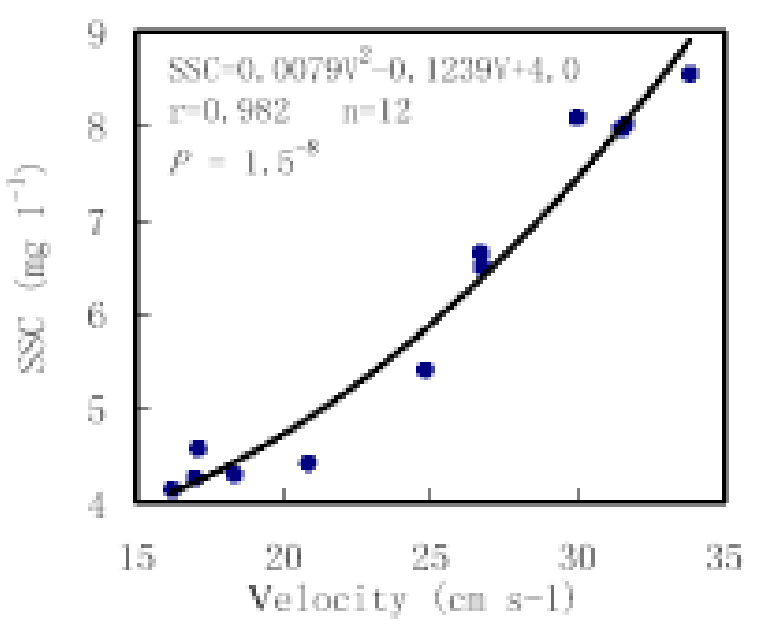

Fig.9. Correlation between tidally-averaged current velocity and SSC at the near-surface level $(V, r, n$ and $\mathrm{P}$ means velocity, correlation coefficient, number of samples and significance level, respectively)

2-tide-lag Tidal range-SSC correlations are significant.

The 10-min interval dataset does not suggest a statistically significant non-zero SSC lag for the near-bed level because the correlation between SSC and velocity decreases progressively as the time lag increases. In other words, the In-phase correlation best reflects the relationship between velocity and SSC. In contrast, the surface correlation between velocity and SSC reaches its highest value at 160 and 170 min SSC lag, suggesting a SSC lag of almost three hours. This statistical lag is consistent with the observation that the near-surface SSC peaks tended to occur during slack water, about three hours later than the peak velocity (Fig. 5).

FLUXES OF SUSPENDED SEDIMENTS (FLOOD VS EBB)

The instantaneous suspended sediment flux ranged between 0.1 and $7.9 \mathrm{~g} \mathrm{~m}^{-2} \mathrm{~s}^{-1}$ near the surface and between 0.4 and 


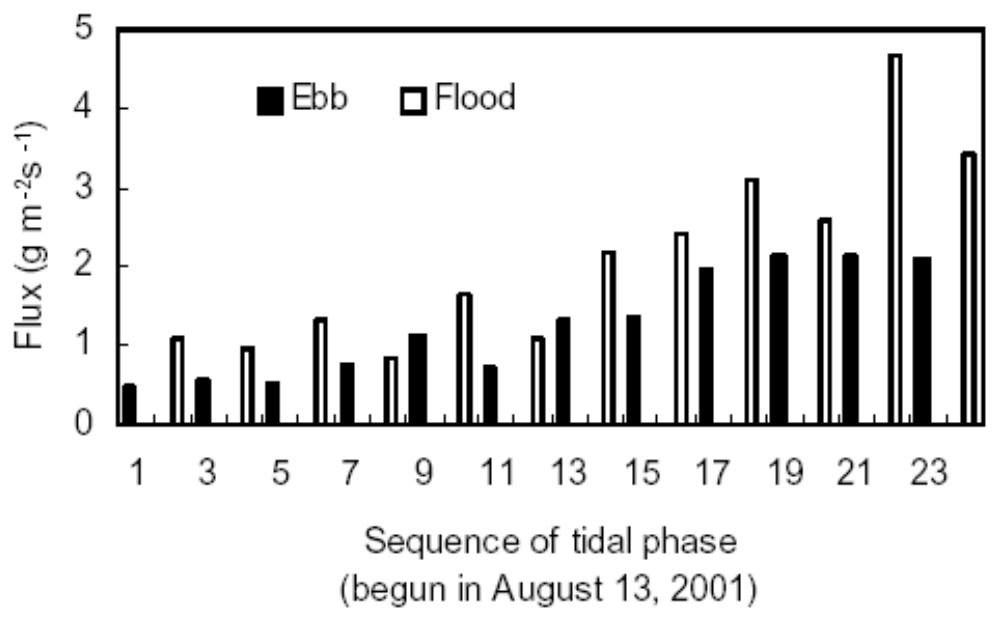

Fig.10. Time series of flood and ebb suspended sediment fluxes at the near-surface level

Table 3. Flood, ebb and residual suspended sediment fluxes through a unit area of cross section at different tidal ranges and vertical levels $\left(\mathrm{kg} \mathrm{m}^{-2} \mathrm{~T}^{-1}\right)^{*}$

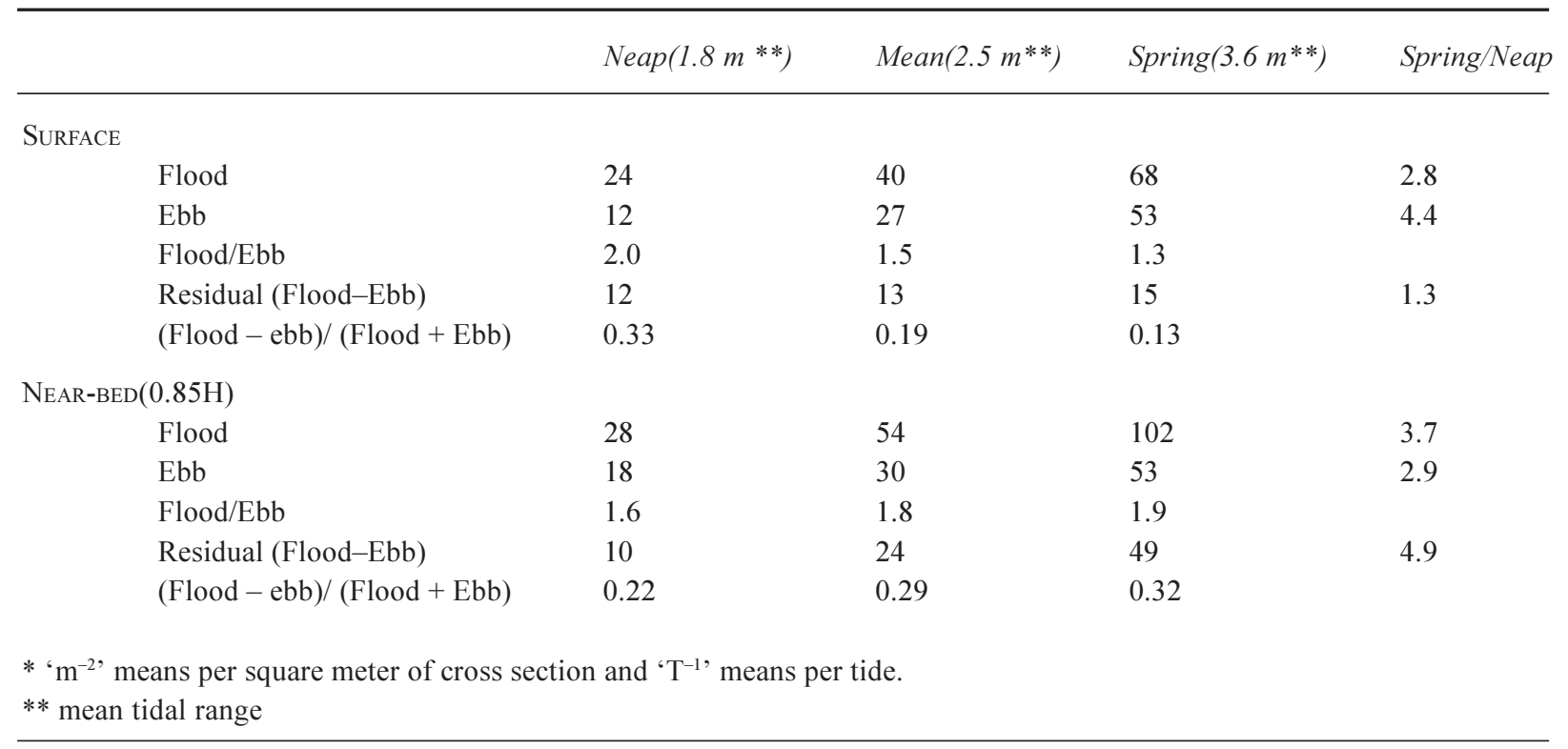

$23 \mathrm{~g} \mathrm{~m}^{-2} \mathrm{~s}^{-1}$ near the bottom. Although ebb duration was typically longer than flood duration, the flood flux was almost always greater than the immediately preceding or following ebb fluxes (Fig. 10) because of significantly higher velocity and SSC during flood than during ebb (Table 1). On average over the neap to spring period, the ratio of flood flux to ebb flux was 1.6 at the surface and 1.8 near the bed (Table 3). Both the flood flux and the ebb flux tended to increase from the neap tides to spring tides (Fig.10 and Table 3). Net transport of suspended sediment at spring tide relative to neap was 1.3 times greater near the surface and 4.9 times greater near the bed (Table 3 ). This is because both velocity and SSC were significantly higher during spring tides than during neap tides (Table 1). The strong spring-neap variability observed here is similar to that observed on the Amazon subaqueous delta, where the nearbed particle flux during spring tides is five times greater than during neap tides (Sternberg et al., 1996).

\section{Discussion}

LOW LEVEL OF SSC

The magnitude of SSCs observed in this study is similar to Wang's (2000) results for Jiaozhou Bay. In the latter study, near surface SSC increased northward from $4 \mathrm{mg} \mathrm{L}^{-1}$ near 
the bay mouth to $14 \mathrm{mg} \mathrm{L}^{-1}$ near the bay head (Wang, 2000). The level of SSC documented in this study, although reaching $40 \mathrm{mg} \mathrm{l}^{-1}$ near the bed, is low compared to that in many other estuaries and embayments, including Chesapeake Bay (Schubel, 1968), the Tamar Estuary (Uncles and Stephens, 1993), the Forth Estuary (Lindsay et al., 1996), the Mekong River Estuary (Wolanski et al., 1996), the Yangtze River estuary (Yang, 1999), Fourleague Bay (Perez et al., 2000), the Bay of Fundy (Amos and Tee, 1989; Schostak et al., 2000) and the Hudson River estuary (Orton and Kineke, 2001). Similarly low SSCs were observed in the Tweed Estuary, where turbidity levels between the mouth and the limit of saline intrusion ranged from 2 to $30 \mathrm{mg} \mathrm{L}^{-1}$ (Uncles and Stephens, 1997). Short and weakly tidal estuaries are expected to have generally low SSCs. High SSCs in estuaries are most likely to be the result of either locally generated wave resuspension, high sediment loads associated with freshets, or intruding seawater carrying suspended sediments derived from coastal wave activity (Uncles et al., 2002). Jiaozhou Bay is short relative to many estuaries such as the Chesapeake Bay (Schubel, 1968) and the Yangtze Estuary (Yang, 1999). Although Jiaozhou Bay is mesotidal to macrotidal (Davies, 1964) (during this field experiment, the average and maximum spring tidal ranges were $3.6 \mathrm{~m}$ and $4.3 \mathrm{~m}$, respectively), its current is weak. For example, the current velocity at the study site was less than $80 \mathrm{~cm} \mathrm{~s}^{-1}$ (Fig.5). With a similar tidal range, the current velocity in the Yangtze estuary is often greater than $200 \mathrm{~cm}$ $\mathrm{s}^{-1}$ (Yang, 1999), more than 2.5 times that in Jiaozhou Bay. None of the three factors identified by Uncles et al. (2002) to be favourable to high SSCs is dominant in Jiaozhou Bay. Firstly, local resuspension is expected to be limited due to weak waves and currents. Secondly, sediment load supplied by the rivers is very low, especially since human activities in the drainage area reduced the riverine water and sediment fluxes dramatically. Thirdly, suspended sediment brought by intruding seawater is minor, because the bed in the vicinity of the inlet comprises coarse sand and boulders, and the region of the adjacent Yellow Sea is also low in $\operatorname{SSC}\left(<10 \mathrm{mg} \mathrm{L}^{-1}\right)$ (Wang and Gao, 2003).

\section{BACKGROUND CONCENTRATION}

According to Schubel (1968), in estuaries there is typically a natural 'background' SSC which increases with depth and whose intensity at any depth is relatively constant over time scales of at least two tidal cycles. In Chesapeake Bay, the background concentration increases from about $15 \mathrm{mg} \mathrm{L}^{-1}$ at the surface to about $20 \mathrm{mg} \mathrm{L}^{-1}$ at a depth of $9 \mathrm{~m}$. The background concentration consists of particles (flocs) made of very fine grains whose settling times are long compared to the vertical mixing time. In Chesapeake Bay, the settling velocity of background particles is only about $0.001 \mathrm{~cm} \mathrm{~s}^{-1}$, which corresponds to a Stokes' diameter of approximately $3 \mu \mathrm{m}$ (Schubel, 1968). Alber (2000) divided suspended sediments into 'non-settleable' ('truly suspended') (settling velocity $<0.006 \mathrm{~cm} \mathrm{~s}^{-1}$ ) and 'settleable' (settling velocity $>0.006 \mathrm{~cm} \mathrm{~s}^{-1}$ ) fractions over the course of a tidal cycle to determine whether these two fractions comprised particles with differing biological and chemical characteristics. In the Ogeechee River Estuary, the majority of the suspended sediment (by weight) was in the truly suspended fraction (Alber, 2000). When compared to the settleable particles, the truly suspended material was found to be significantly higher in percentages of POC, chlorophyll, phaeopigment and weight-specific maximal uptake rates of both enzymes, providing clear evidence for a qualitative distinction between the two fractions (Alber, 2000).

The present study provides further evidence for the significance of the background SSC concept. It can be concluded from Figs. 4 and 5 that: (a) the surface background SSC is generally lower than the near-bed background SSC, which is consistent with the observation by Schubel (1968); (b) the background SSC of a given tidal cycle is nearly the same as that of the neighbouring tidal cycles but background SSC increases along with the tidal range, especially at the surface; (c) the difference between background SSC and peak SSC increases with depth, which agrees with the result of Schubel (Fig. 2 of Schubel, 1968); and (d) during periods of low water energy (neap tides in combination with calm weather), the mean surface SSC tends to decrease towards the background SSC, with its fluctuations being diminished (Fig. 5). Compared to the results of Schubel (1968), both the surface background SSC (about 3.0 to $5.5 \mathrm{mg} \mathrm{L}^{-1}$ ) and the near-bed background SSC (about 4.0 to $8.0 \mathrm{mg} \mathrm{L}^{-1}$ ) in Jiaozhou Bay are lower than those in Chesapeake Bay. This difference may be attributed to weaker currents and weaker suspension of sediments in Jiaozhou Bay. In combination with the results of Schubel (1968), it may be concluded that: (a) there is always a background SSC in estuarine and coastal waters with significant tidal currents (in other words, SSC never reduces to zero over the tidal cycle); the background SSC increases with water energy, with the local mean SSC, and as the bed is approached; (c) the fundamental cause for background SSC is that water energy in tidal estuaries is never low enough for long enough to allow all the suspended sediment to settle to the bed. In Jiaozhou Bay, the background SSC is about $1 / 2$ to $1 / 3$ of the mean SSC (Figs. 4 and 5 and Table 1). If the background SSC consists of the finer component of the suspended sediment population, the background SSC should comprise the finer $1 / 2$ to $1 / 3$ portion of the cumulative 
grain size curve. According to the grain size distribution of suspended sediment samples from Jiaozhou Bay, the finer $1 / 2$ to $1 / 3$ portion consists of particles with a median grain size of 3 to $5 \mu \mathrm{m}$, which is close to the result of Schubel (1968). Aggregation of clay minerals occurs in waters with different salinities (Krone, 1978; Gibbs, 1983; Dyer, 1986; Chen et al., 1988).

\section{RELATIVE IMPORTANCE OF ADVECTION AND SETTLING/RESUSPENSION IN CONTROLLING VARIABILITY OF SSC}

The near-surface SSC at the study site tended to be higher at the end of ebb and lower at the end of flood. In other words, SSC decreased during flood and increased during ebb. This pattern suggests a dominance of horizontal advection over settling/resuspension in controlling the semidiurnal variation in SSC. SSC is expected to have two peaks during a single tidal cycle if the variability of SSC is governed by settling/resuspension. In the Forth Estuary, for instance, peak SSC ranging from 130 to $300 \mathrm{mg} \mathrm{L}^{-1}$ (an order of magnitude greater than Jiaozhou Bay) occurs near maximum flood and ebb velocity, while minimum SSC is found near flood and ebb slack 5, 10 and $20 \mathrm{~m}$ above the bed (Lindsay et al., 1996). Similar patterns have been observed in many other tidal environments such as Chesapeake Bay (Schubel, 1968). The salinity of the present study varied between 25 and 31 , similar to that in Chesapeake Bay (Schubel, 1968). Thus, the grain size property of suspended particles in the two bays is likely to be comparable.

The near-surface dominance of SSC by advection in this study is likely related to the local physical setting. As shown in Fig.1, the water depth in Jiaozhou Bay decreases sharply northward and northwestward from the deep channel of the bay mouth landward toward intertidal flats. The bed of the mouth channel comprises coarse sand, rock and boulders because of erosion (Wang, 2000). In contrast to this, the main area of the bay itself is covered by mud (Li, 1983). According to the magnitude of flood and ebb velocity documented in Table 1, the near-surface suspended particles are likely to move back and forth over about 3 to $4 \mathrm{~km}, 5$ to $6 \mathrm{~km}$ and 7 to $8 \mathrm{~km}$ during a semidiurnal neap tide, mean tide and spring tide, respectively. The current direction at the study site determined from the ADP was typically northwestward during flood and southeastward during ebb. Thus, a near-surface particle found at mean tidal level at the study site is anticipated to move northwestwards to the $5 \mathrm{~m}$ contour during a mean tidal flood and to between the 5 $\mathrm{m}$ and $2 \mathrm{~m}$ contours during a spring tidal flood. During ebb, the particle would move southeastwards towards the $30 \mathrm{~m}$

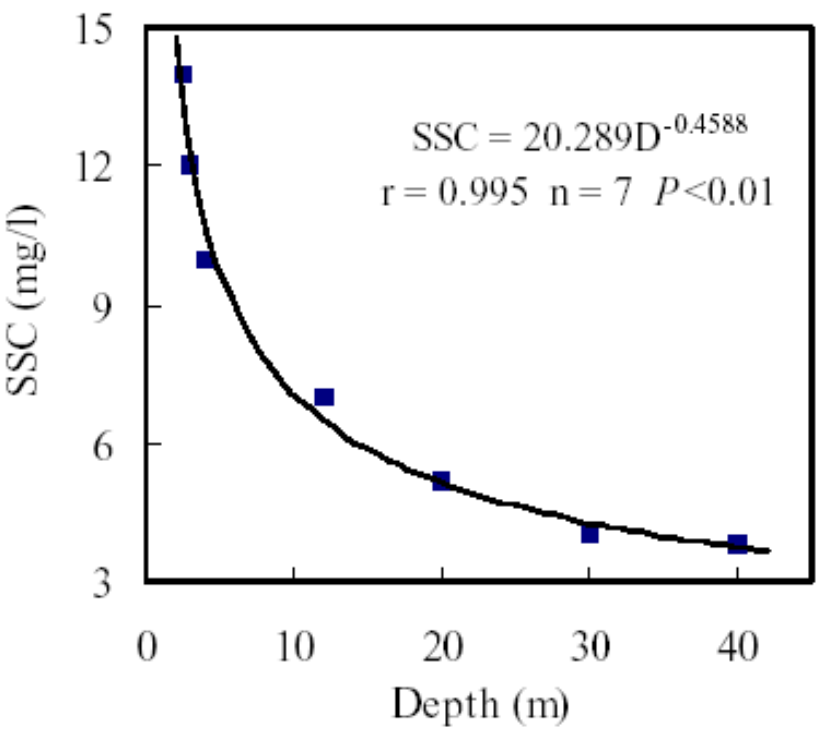

Fig. 11. A negative relationship between surface SSC and water depth in Jiaozhou Bay [based on SSC isolines and corresponding depths by Wang (2000); $D, r, n$ and $\mathrm{P}$ are depth, correlation coefficient, number of samples and significance level, respectively.

contour. Bed sediment is easier to resuspend by waves and currents in shallow water than in deep water (Carter, 1988; Trenhaile, 1997). In San Francisco Bay, for example, zones of high SSC in shallow sub-embayments are associated with wind-wave resuspension (Ruhl et al., 2001). This basic tendency of sediment dynamics, in combination with the spatial distribution in availability and stability of the bed sediment, is assumed to generate a trend of increasing nearsurface SSC from the channel mouth to the bay head. This spatial pattern was also examined through field observations and by analysis of remotely sensed data by Wang (2000). As shown in Fig. 11, near-surface SSC is correlated negatively with water depth where the sample for SSC was obtained, being about twice as high at $5 \mathrm{~m}$ depth as at $20 \mathrm{~m}$ depth. The horizontal gradient of SSC and weak vertical exchange of sediment due to low water energy are responsible for higher SSC at ebb slack water and lower SSC at flood slack water.

In contrast with the surface, SSC near the bed corresponded well to changes in current velocity (Fig. 4). This suggests that the variation in SSC near the bed was controlled by resuspension/settling processes associated with cyclic changes in current velocity. The influence of local resuspension on near-bed SSC is greater because the near-bed level is much closer to the source of sediment, especially considering the $20 \mathrm{~m}$ water depth. In addition, the horizontal exchange of water that drives horizontal advection of SSC is weaker near the bed due to lower current velocities (Table 1). 
RELATIONSHIP BETWEEN SSC AND TIDAL DYNAMICS

Correlations between daily-averaged SSC and tidal range in the Tamar Estuary (Uncles et al., 1994) and other estuaries (Uncles et al., 2002) typically suggest a strong dependence of SSC on tidal range. It is reasonable to use tidally-averaged values to replace daily-average values in this study because the tidal cycle in Jiaozhou Bay is 12 hrs and 25 minutes rather than a day or exactly half a day. The motion of sediment is controlled by flow (Dyer, 1986) rather than by the rise and fall of water level. Because the tidally-averaged current speed increases along with tidal range (Table 1), SSC is also correlated significantly with tidal range (Table $2)$. The significant correlation between SSC and tidal dynamics in this study indicates that the motion of sediment in Jiaozhou Bay is governed by tides rather than by waves, at least over spring-neap time scales in calm weather. In some estuarine and coastal waters, on the other hand, waves overwhelm tides in controlling the variability of SSC. In the Tweed Estuary, for instance, the correlation between turbidity and tidal range was poor, while that between turbidity and wave height explained over $90 \%$ of the variance in turbidity (Uncles and Stephens, 1997).

The correlation between short interval (10 min) SSC and current velocity is also influenced by water depth. Near the bed, SSC corresponds well to variations in current velocity, which results in a significant correlation between SSC and current velocity (Fig.7). At the surface, however, the short interval SSC is poorly correlated to current velocity because the current is not strong enough to induce turbulence that can move sediment upward through a water column of $20 \mathrm{~m}$.

\section{RESIDUAL TRANSPORT OF SUSPENDED SEDIMENT}

The direction and flux of residual sediment transport are important aspects of sediment dynamics (Green et al., 1995; Lindsay et al., 1996; Lane et al., 1997; Bassoullet et al., 2000; Dyer et al., 2000; Ridderinkhof et al., 2000; Alvarez and Jones, 2002). In the past, the nature of residual suspended sediment transport in Jiaozhou Bay has been controversial (Wang et al., 1982; Liu and Li., 1986; Zhao and Liu, 1993; Wang et al., 1999; Wang, 2000; Wang et al., 2000; Gao and Wang, 2002; Wang and Gao, 2004). Wang et al. (1982) assumed residual sediment transport to be landward, because current velocity is higher at the mouth than in the main bay and is higher during flood than during ebb. This assumption did not account for the fact that residual sediment flux is related not only to current velocity but also to SSC and the duration of flood and ebb. In contrast, Liu and Li (1986) concluded that riverine sediments are all transported out of the bay because the bay has not recently been changed by accretion. In fact, deposition has been continual since the formation of the bay about 10, 000 years ago (Wang et al., 1982; Li, 1983, 2000). Zhao and Liu (1993) and SOA (1993) deduced that riverine sediment cannot be transported out of the bay because of the weak currents and flood dominance. At the mouth of the bay, Hu et al., (2000) documented flood and ebb SSC and concluded that exchange of suspended sediment between the bay and the open sea was weak. Using ADCP masurements, Gao and Wang (2002) observed a seaward net suspended sediment flux of $1,000 t$ per spring tide through the cross section of the bay mouth, although the time interval of their velocity and SSC observations was relatively long (2 to 3 hours). Further study is needed to resolve the above controversy.

When net flux is less than a few percent of the total flux for a single tide, flood or ebb dominance typically cannot be determined with confidence (Lane et al., 1997). Table 3 shows that the ratio of net flux to total tidal flux at the study site is 0.22 to 0.32 , conclusively indicating flood dominance of suspended sediment transport at the study site. The residual transport direction (about $330^{\circ}$ ) is consistent with the net transport direction indicated by bed sediment grainsize trends using the method of Gao and Collins (1992) (Wang, 2000). The cause for landward residual transport is flood dominance of both current and SSC (Table 1). The observed flood dominance of the current is likely to be related to the geometry of the approach to the mouth of the bay. The gorge connecting Jiaozhou Bay and the Yellow Sea acts much as a typical inlet in a barrier-lagoon system. On the lagoon side of the inlet, currents in the central portion of the inlet channel tend to be flood dominated, whereas currents on both sides of the channel are typically ebb dominated (Hayes, 1980; Trenhaile, 1997). It is reasonable to assume that the site of this study (Fig. 1) is located in the area of expected flood dominance. In combination with higher SSC during flood than during ebb at the site (Table 1), a landward residual suspended sediment flux results.

Residual suspended sediment transport in tidal estuaries is complicated. It often varies spatially and temporally. For example, in the Ems-Dollard estuary, net transport of sediment is highly variable. Under fair weather conditions, there is a relatively small net transport towards the higher levels of the tidal flat. When the wind speed increases, the net transport increases drastically (Ridderinkhof et al., 2000). In the Dollard Estuary, ebb dominance is not apparent in the sediment fluxes during calm weather but, in periods of high winds, the flux is likely to be ebb directed. The overall response to winds is similar on flood dominated mudflats (Dyer et al., 2000). On the British North Sea Shelf, a wind-driven flow distorted the tidal ellipse and caused a net transport of sediment along- and off-shore; depth- 
integrated sediment transport during the storm was up to two orders of magnitude greater than prior to the storm under tidal currents alone (Green et al., 1995). Within the 'Baie de Marennes-Oleron' in France, residual sediment fluxes are onshore during spring tides but offshore during periods of wave domination (Bassoullet et al., 2000). In the Forth Estuary, Lindsay et al. (1996) found near-bed residual sediment transport to be landward, whereas near-surface residual sediment transport was seaward. In the present study, residual sediment is landward both at the surface and close to the bed during all the observed neap, mean and spring tides (Table 3 ). There are likely three causes for this, although the first one is the dominant: (a) the inlet effect; (b) limited riverine discharge. As addressed before, the ratio of riverine discharge to tidal discharge is less than $5 \%$. If the riverine discharge were increased, the current and sediment fluxes at the study site might become ebb dominated, at least at the surface as in the Forth Estuary (Lindsay et al., 1996); (c) calm weather. Winds were weak during the period of observation. If a storm hit the bay, resuspension would be enhanced especially in the northern shallow area; this might lead to much higher SSC within the bay than in the Yellow Sea and result in a seaward residual sediment flux, as in the Dollard Estuary (Dyer et al., 2000).

Although the direction of residual sediment transport is clear at this study location, the net fluxes are relatively low. Thus, the near-bed net sediment fluxes of $0.22 \mathrm{~g} \mathrm{~m}^{-2} \mathrm{~s}^{-1}$ during the neap tides and $1.1 \mathrm{~g} \mathrm{~m}^{-2} \mathrm{~s}^{-1}$ during the spring tides (Table 3) are much lower than the $25 \mathrm{~g} \mathrm{~m}^{-2} \mathrm{~s}^{-1}$ observed (during the neap tides) in the upper Gulf of California (Alvarez and Jones, 2002). The low magnitude of net sediment flux in Jiaozhou Bay is attributed to low SSC and weak currents (Table 1).

\section{SSC LAG}

There is very little SSC lag at the near bed level, because this level quickly responds to sediment exchange between the bed and the water column. It is reasonable to deduce that the surface level is much slower in responding to sediment exchange between the bed and the water column because of the larger depth $(20 \mathrm{~m})$. For the inter-tidal case, the surface SSC is related not only to the In-phase tide but also to the previous one to two tides, suggesting a surface SSC lag at longer time scales.

\section{Conclusions}

Compared to those in many other estuarine and coastal waters, the mean suspended sediment concentration (SSC) and background concentration in the study area are low because of low water energy and limited fine-grained sediment supply. However, semidiurnal and neap-spring cyclic variations in SSC are apparent in calm weather. Close to the bed, the variability of SSC is governed by settling/ resuspension processes and SSC is highly correlated with instantaneous current velocity with almost no time lag. Near the surface (about $20 \mathrm{~m}$ above the bed), the variability of SSC is controlled instead by horizontal advection, with the peak SSC tending to occur at the end of ebb. The advection dominance is attributed to the landward increase in nearsurface SSC and the weakness in vertical sediment exchange. Because of the dominance by advection, the correlation between instantaneous SSC and current velocity is poor. On the other hand, tidally-averaged SSC is correlated significantly with tidally-averaged current speed and tidal range, both near the bed and at the surface. Statistically, there seems to be no SSC lag except for the surface velocitySSC correlation that suggests an about one-tide lag. A statistically significant time lag of about one-tide was also found between near-surface velocity and SSC. Flood dominance in current velocity and SSC results in a significant landward residual suspended sediment transport through the central portion of the inner mouth of the inlet connecting the bay and the open sea. The flood dominance is mainly attributed to the geometry of the inner mouth of the inlet, which favours flow separation on the flood but not on ebb.

\section{Acknowledgements}

This research was supported by the China Natural Science Foundation (No. 40036010) and the National Great Science Project of China (2002CB412407). The authors acknowledge Mr. H.T. Chen and Mr. L. Huang for joining the field work. Dr. C.T. Friedrichs helped by providing reference articles and improving the English.

\section{References}

Alber, M., 2000. Settleable and non-settleable suspended sediments in the Ogeechee River estuary, Georgia, U.S.A.. Estuar. Coast. Shelf Sci., 50, 805-816.

Alvarez, L.G. and Jones, S.E., 2002. Factors Influencing Suspended Sediment Flux in the Upper Gulf of California. Estuar. Coast. Shelf Sci., 54, 747-759.

Amos, C.L. and Tee, K.T., 1989. Suspended sediment transport processes in Cumberland Basin, Bay of Fundy. J. Geophys. Res., 94, 14407--14417.

Bassoullet, P., Hir, P. Le, Gouleau, D. and Robert, S., 2000. Sediment transport over an intertidal mudflat: field investigations and estimation of fluxes within the "Baie de Marenres-Oleron" (France). Cont. Shelf Res., 20, 1635-1653. 
Carter, W.R.. 1988. Coastal Environments. Academic Press, San Diego, USA.

Chen, B.L., Wu, L. and Qiu, P.Y., 1988. Mechanism of agglomeration of suspended matter in the South Passage of Changjiang River mouth. In: Dynamic Processes and Morphological Evolution of the Changjiang River mouth, J.Y.Chen, H.T. Shen and C.X.Yun (Eds.) Shanghai Science and Technology Press. Shanghai, China. 276-282.

Davies, J.L., 1964. A morphogenic approach to world shorelines. Z. Geomorphologie 8, 127-142.

Dyer, K.R., 1986. Coastal and estuarine sediment dynamics. Wiley, Chichester, UK.

Dyer, K.R., Christie, M.C., Feates, N., Fennessy, M.J., Pejrup, M. and van der Lee, W., 2000. An investigation into processes influencing the morphodynamics of an intertidal mudflat, the Dollard Estuary, The Netherlands: I. Hydrodynamics and Suspended Sediment. Estuar. Coast. Shelf Sci., 50, 607-625.

First Institute of Oceanography (FIO), SOA, 1984. Physical environments of Jiaozhou Bay. China Ocean Press, Beijing, China.

Gao, S. and Collins, M., 1992. Net sediment transport patterns inferred from grain-size trends, based upon definition of "transport vectors". Sediment. Geol., 81, 47-60.

Gao, S. and Wang, Y.P., 2002. Characteristics of sedimentary environment and tidal inlet evolution of Jiaozhou Bay. Adv. Mar. Sci., 20, 52-59 (in Chinese with English abstract).

Gelfenbaum, G., 1983. Suspended-sediment response to semidiurnal and fortnightly tidal variations in a mesotidal estuary: Columbia River, U. S. A. Mar. Geol., 52, 39-57.

Gibbs, R.J., 1983. Coagulation rates of clay minerals and natural sediments. J. Sediment. Petrol., 53, 1193-1203.

Green, M.O., Vincent, C.E., McCave, I.N., Dickson, R.R., Rees, J.M. and Pearsons, N.D., 1995. Storm sediment transport: observations from the British North Sea shelf. Cont. Shelf Res., 15, 889-912.

Hayes, 1980. General morphology and sediment patterns in tidal inlet. Sediment.Geol., 26, 139-156.

Hill, D.C., Jones, S.E. and Prandle, D., 2003. Derivation of sediment resuspension rates from acoustic backscatter timeseries in tidal waters. Cont. Shelf Res., 23, 19-40.

Hu, Z.J., Biao, S.H., Zhao, K.G., Xia, D.X., Wu, S.Y. and Feng, A.H., 2000. Forecast techniques on siltation hazards in semienclosed bays: a case study from Jiaozhou Bay. First Institute of Oceanography, Qingdao, China.

Krone, R.B., 1978. Aggregation of suspended particles in estuaries. In: Estuarine Transport Processes, B. Kjerfve (Ed.) University of South Carolina Press, Columbia, USA. 177-190.

Lane, A., Prandle, D., Harrison, A.J., Jones, P.D. and Jarvis, C. J., 1997. Measuring fluxes in tidal estuaries: Sensitivity to instrumentation and associated data analyses. Estuar. Coast. Shelf Sci., 45, 433-451.

Li, F., Zhang, H.M. and Song, H.L., 1992. Sedimentary Environment. In: Ecology and Biological Resource of the Jiaozhou Bay, R.Y. Liu (Ed.). Academic Press, Beijing, China. 4-19.

Li, S.W., 1983. Formation and evolution of the Jiaozhou Bay based on sedimentary characteristics. Acta Oceanol. Sinica, 5, 328339 (in Chinese).

Lindsay P., Balls P.W. and West J. R., 1996. Influence of Tidal Range and River Discharge on Suspended Particulate Matter Fluxes in the Forth Estuary (Scotland). Estuar. Coast. Shelf Sci., $42,63-82$.

Liu, X.X. and Li, X.T., 1986. The life time of Jiaozhou Bay: a preliminary study. Chinese Coast. Eng., 5, 25-30.
Orton, P.M. and Kineke, G.C., 2001. Comparing Calculated and Observed Vertical Suspended-Sediment Distributions from a Hudson River Estuary Turbidity Maximum. Estuar. Coast. Shelf Sci., 52, 401-410.

Perez, B.C., Day, Jr. J.W., Rouse, L.J., Shaw, R.F. and Wang, M., 2000. Influence of Atchafalaya River discharge and winter frontal passage on suspended sediment concentration and flux in Fourleague Bay, Louisiana. Estuar. Coast. Shelf Sci., 50, 271290

Qiao, P. N., Zhou, Z. D. and Zhang, H. L., 1994. Evolution of Estuaries in China. Academic Press, Beijing, China.

Ridderinkhof, H., van der Hama, R. and van der Lee, W., 2000. Temporal variations in concentration and transport of suspended sediments in a channel-flat system in the Ems-Dollard estuary. Cont. Shelf Res., 20, 1479-1493.

Ruhl, C.A., Schoellhamer, D.H., Stumpf, R.P. and Lindsay, C. L., 2001. Combined Use of Remote Sensing and Continuous Monitoring to Analyse the Variability of Suspended-Sediment Concentrations in San Francisco Bay, California. Estuar. Coast. Shelf Sci., 53, 801-812.

Schoellhamer, D.H., 2002. Variability of suspended-sediment concentration at tidal to annual time scales in San Francisco Bay, USA. Cont. Shelf Res. 22, 1857-1866.

Schostak, L.E., Davidson-Arnott, R.G.D., Ollerhead, J. and Kostaschuk, R. A., 2000. Patterns of flow and suspended sediment concentration in a macrotidal saltmarsh creek. Bay of Fundy, Canada. In: Coastal and Estuarine Environments: sedimentology, geomorphology and geoarchaeology, K. Pye and J. R. L. Allen (Eds.). The Geological Society, London, UK 59-76.

Schubel, J.R., 1968. Turbidity maximum of the northern Chesapeake Bay. Science 161, 1013-1015.

Shen, Z. L., 2001. Historical changes in nutrient structure and its influences on phytoplantkon composition in Jiaozhou Bay. Estuar. Coast. Shelf Sci., 52, 211-224.

State Oceanographic Administration (SOA), 1993. China's Estuaries and Embayments (Vol.4) -Southern Shandong Penisular and Jiangsu Province. China Ocean Press,.Beijing, China.

Sternberg, R.W., Cacchione, D.A., Paulson, B., Kineke, G.C. and Drake, D.E., 1996. Observations of sediment transport on the Amazon subaqueous delta. Cont. Shelf Res., 16, 697-715.

Trenhaile, A.S., 1997. Coastal Dynamics and Landforms. Clarendon Press, Oxford, UK.

Uncles, R.J. and Stephens, J.A., 1993. Nature of the Turbidity Maximum in the Tamar Estuary, U.K. Estuar. Coast. Shelf Sci., 36, 413-431.

Uncles, R.J. and Stephens, J.A., 1997. Dynamics of Turbidity in the Tweed Estuary. Estuar. Coast. Shelf Sci., 45, 745-758.

Uncles, R.J, Barton, M.L. and Stephens, J.A., 1994. Seasonal Variability of Fine-sediment Concentrations in the Turbidity Maximum Region of the Tamar Estuary. Estuar. Coast. Shelf Sci. 38, 19-39.

Uncles, R.J, Stephens, J.A. and Smith, R.E., 2002. The dependence of estuarine turbidity on tidal intrusion length, tidal range and residence time. Cont. Shelf Res., 22, 1835-1856.

Wang, W.H., Wang, S.Y. and Zhang, S.X., 1982. Sediment supply and natural deposition rate of Jiaozhou Bay. Chinese Coast. Eng., 1, 83-90.

Wang, Y.P., 2000. Sediment dynamics of Jiaozhou Bay and its adjacent areas. Institute of Oceanology, Chinese Academy of Science, Qingdao, China.

Wang, Y.P. and Gao, S., 2004 (in press). Measurements of suspended sediment flux at a bay mouth using a vessel-mounted ADCP. J. Coast. Res. 
Wang, Y.P., Gao, S. and Li., K.Y., 1999. A preliminary study on the suspended sediment concentration measurements using a vessel-mounted ADCP. Oceanol. Limnol. Sinica 30, 758-763.

Wang, Y.P., Gao, S. and Jia, J.J., 2000. Sediment distribution and transport patterns in Jiaozhou Bay and adjoining areas. Acta Geogr. Sinica, 55, 449-458.

Wolanski, E.; Nguyen, N.H., Le, T.D., Nguyen, H.N. and Nguyen, N.T., 1996. Fine-sediment Dynamics in the Mekong River Estuary, Vietnam. Estuar. Coast. Shelf Sci., 43, 565-582.

Yang, S.L., 1999. Tidal wetland sedimentation in the Yangtze Delta. J. Coast. Res., 15, 1091-1099

Zhao, Q.J. and Liu, F.S., 1993. The principal environmental problem of Jiaozhou Bay: decrease in water area. Chinese Coast. Eng., 12, 63-67. 